\title{
Interrogating the Non-Justiciability of Constitutional Directive Principles and Public Policy Failure in Nigeria
}

\author{
Taiwo A. Olaiya ${ }^{1}$ \\ ${ }^{1}$ Department of Public Administration, Obafemi Awolowo University, Ile-Ife, Nigeria \\ Correspondence: Taiwo A. Olaiya, Department of Public Administration, Obafemi Awolowo University, Ile-Ife, \\ Nigeria. Tel: 234-80-3344-7396; 234-80-8819-6493. E-mail: olaiyapoju2@yahoo.co.uk; olaiyata@oauife.edu.ng
}

Received: May 13, 2015 Accepted: May 22, 2015 Online Published: July 4, 2015

doi:10.5539/jpl.v8n3p23 URL: http://dx.doi.org/10.5539/jpl.v8n3p23

\begin{abstract}
The fundamental objectives and directive principles of state policy, contained in Chapter II of the 1999 Constitution of the Federal Republic of Nigeria, are guidelines to the federal and state governments of Nigeria to promote social order. As framed, the objectives appear to encompass social inclusiveness with a view to reducing socio-economic and political inequality in status and opportunities among individuals and corporate entities. Grosso modo, the directives should ordinarily be kept in mind while framing laws and public policies in nigeria. Among others, the Chapter provides for political, economic, social, educational, foreign policy and environmental objectives of state policy, which roughly correlate with the third generation rights now recognized by the United Nations Organisation's 1948 Universal Declaration of Human Rights. Potentially, the provisions could also appropriate the key attributes to good governance as recognised by the United Nations and the World Bank Governance Indicators, if properly administered. However, despite the principles laid down therein considered fundamental in the governance of the country and which could have induced a duty from the state to apply these principles in making laws and policies for just and equitable administration of the country, these provisions are not enforceable by any court in Nigeria vide a counter-provision in section 6, sub-section (6), paragraph (c) of the 1999 Constitution, which makes the objectives non-justiceable. This paper thus analysed the logical repercussions of the non-justiciability of this important chapter vis-à-vis the Nigerian pervasive atmosphere of public policy failure. The paper utilised sequential logic of social narratives to interrogate the legal imports of this aspects of the Constitution, most especially for the attainment of the objectives contained Chapter II against the backdrop of Section 6(6)(c). The paper concluded, among others, that there is urgent need to subject the objectives to binding governmental obligations to avoid the general lackluster attitude towards public policies in Nigeria.
\end{abstract}

Keywords: socio-economic and cultural rights, public policy, human and civil rights, constitutionalism, Nigeria, Africa, governance crisis

\section{Introduction}

Apart from being the basic and entrenched rules governing the conduct of governments and citizens in a nation-state, and establishing governance concept, character, and structure, the constitution of a state is the fundamental law from which all other laws and institutions take departure. The Black's Law Dictionary defines constitution as 'the fundamental and organic law of a nation or state that establishes the institutions and apparatus of government, defines the scope of governmental sovereign powers, and guarantees individual civil rights and civil liberties.' It is discernible from the definition that the institutions, organs, agencies and even government officials exist by virtue of the constitution (Babalola, 2010). Babalola (2010) argued that it is thus expected of the holders of the offices to exercise the powers conferred on the offices according to the provisions of the constitution. For the purpose of this paper, the latter part of a constitution, as defined by the Black's Law Dictionary whereby the social rights of citizens are guaranteed is instructive.

Coming from the background of the historical school of jurisprudence and relating it to the modern legal systems, constitutions could easily be seen to sum up the accepted customs and popular faith of the people and can be regarded as volksgeist, the spirit of the people. It is the fundamental law from which all other laws and policies take their validity. A constitution embodies the fundamental principles of a government. A Constitution, once adopted by the sovereign power, is amendable by that power stated only therein. All laws, executive actions, public 
policies and judicial decisions must conform to the Constitution, as it is the creator of the powers exercised by the departments of government and other bodies within the polity. Circa, constitutions are indispensable for administration of a state. Apart from its empowerment of the state; establishing values and ideas of democracy, freedom or liberty, peoples' welfare, equality and justice; and lends legitimacy to the territorial integrity of a nation, a fundamental significance of constitution is that it serves as the linkage between the citizens and the state by the provisions of inalienable rights and duty-bound obligation in reciprocity. Thus, there is no gainsaying the fact that constitutions must be well grounded to guide all policies emanating from all and sundry and societies that make up a state, as much as possible.

In Nigeria, the supremacy of the constitution over all persons and institutions is indubitable. Section 1 of the 1999 Constitution states, inter alia, that the 'Constitution is supreme and its provisions shall have binding force on the authorities and persons throughout the Federal Republic of Nigeria. The constitution also states that every action of the institutions and persons within the country must conform to the provisions of the constitution, as a matter of necessity, or be rendered void to the extent of its inconsistency. To this extent, all government and non-governmental bodies are expected to equate the policies of their operations within the ambit of the constitution and the purpose contained in the constitution. Essentially, the purposes of the Nigerian State are contained in Chapter II and tagged the Fundamental Objectives and Directive Principles of State Policy. Ordinarily, the Fundamental Objectives and Directive Principles of State Policy are the basic principles to guide the policies, which are expected to be variously utilised for Nigeria to realize the national ideals.

These principles do not appear on the Constitution by default. They are echoes of human struggles and successes recorded in the American Declaration of Independence in 1776 and the adoption of Federal Constitution in 1787; the French Revolution in 1789; the Bill of Rights appended to the American Constitution in 1791. Hence, it is discernible that the struggle for the entrenchment of the rights of man has been part and parcel of revolutions. Indeed, by $19^{\text {th }}$ Century, nearly all civilized countries of the world have established a constitutional framework whose underlining tenets are human rights. However, the root of the modern system of socio-economic and cultural rights, as distinct from civil and political rights, was laid in the Universal Declaration of Human Rights in 1948. The declaration, though clearly distinguished between the two types of rights, was quick to affirm their equal importance as conjoined entitlements. Indeed, indication as to the interdependence and indivisibility and equivalence of all human rights, whether civil and political or whether economic, social and cultural, was put on the front burner while discussions about the adoption of the Universal Declaration of Human Rights was on-going in December 1948. To that extent, two covenants for the implementation of the treaties were established, namely, the International Covenant o Economic Social and Cultural Rights (ICESCR) and the International Covenant on Civil and Political Rights (ICCPR), pari passu.

As iterated earlier, the Nigeria 1999 Constitution contains relevant provisions that bear direct connection with the two covenants above-mentioned. However, despite the principles laid down therein considered fundamental in the governance of the country and which could have induced a duty from the state to apply these principles in making laws and policies for just and equitable administration of the country, these provisions are not enforceable by any court in Nigeria vide a counter-provision in section 6, sub-section (6), paragraph (c) of the Nigerian 1999 Constitution, which makes the objectives non-justiceable. This paper thus analysed the logical repercussions of the non-justiciability of this important chapter vis-à-vis the Nigerian pervasive atmosphere of public policy failure. The paper utilised sequential logic of social narratives to interrogate the legal imports of this aspects of the Constitution, most especially for the attainment of the objectives contained Chapter II against the backdrop of Section 6(6)(c). The paper concluded, among others, that there is urgent need to subject the objectives to binding governmental obligations to avoid the general lackluster attitude towards public policies in Nigeria.

\section{The Contextual Domain of Public Policy and Fundamental Objectives}

An objective could be said to be fundamental to a thing when it serves as a source or origin to another or basis for the existence and relevance of that thing. Grosso modo, it is likable to the concept of quid pro quo, because of that therefore this. As Duru (2013:4) pointed out, the whole essence of Fundamental Objectives and Directive Principles stipulated in Chapter II of the 1999 Constitution is reflected in the dictum of Justice Bhagwati's in Minerva Mills v. Union (Note 1) of India that:

...to a large majority of people who are living in almost subhuman existence in conditions of abject poverty and for whom life is one long unbroken story of want and destitution, notions of individual freedom and liberty, though representing some of the cherished values of a free society would sound as empty words bandied about in the drawing rooms of the rich and 
well-to-do, and the only solution for making these rights meaningful to them [is] to remake the material conditions and usher in a new social order where socio-economic justice [will] inform all institutions of public life so that the preconditions of fundamental liberties for all may be secured.

For instance, Okeke (2011) pointed out that as beautiful as these objectives are for the realisation of enduring policies against profligacy in Nigeria, the anti-thesis provided within the same constitution in section 6 most probably accounted for the recurring crisis of corruption in Nigeria, despite numerous legislations and other regulations in the country. According to him:

the drawback to the appropriation of these 'dreams' or objectives by citizens as of right is the provision in section 6, sub-section (6), paragraph (c) of the 1999 Constitution which makes the objectives non-justiceable. There is an urgent need to delete the above provision from the Constitution and subject the objectives to binding governmental obligations known as Constitutional Projects which would encourage the use of public fund for common good.

(Okeke, 2011: 176)

It is given in any society that governmental entities at all levels enact laws in a broad sense. Such entities then embark on policies that will allocate resources for the purpose of promoting the greatest welfare of the greatest number of people. This appears to (or should) be the fundamental objectives of governments for which public policies are the vehicle. In that regards, Olaiya, 2010 argued radically that public policy itself can be generally defined as a system of laws, which manifest in regulatory measures and courses of action instituted with a view to give human face to the programmes of governments.

A major aspect of public policy is its benefit to the people. Public policy is the particularized action embarked upon by governments to combat a critical setback or anticipated crisis of public concern. Such actions are directly linked to certain laws, which in themselves are linked to the constitution. In a Nigerian sense, the law includes specific legislation, case laws, received English laws, the Statutes of General Application and more broadly defined provisions of international law. In all spheres of governance, local, state, federal, and international government organizations all craft and implement public policy to protect and benefit their populations. Such responsibility, arguably, cannot be fostered in vacuum. There has to be a pedestal upon which the tenors will rest for optimum delivery. Once this is done, the role of government will then shift to guiding and influencing the inertia of public policies, rather than making them (Newman, 2001). This is especially considered germane because public policy has long been influenced by a cross section of plural actors determining the direction of public policy, notwithstanding whether from inside or outside government (Newman, 2001:18-23). Thus, the 'interplay of power-wielding interest groups [influencing things in] policy-making process' ( is an important area for which interest should be diverted and adequacy of holistic plan put in place to addressing the dynamics that will be inevitably created as it were. This opinion becomes more robust considering the hallowed claim that a very important aim of governance is to ensure that government acts in the public's interest (Little, 1996:347) and grounding the mechanism in justiceable constitutional provision would most definitely forestall government run as 'a closed viable system that produces itself' as an offshoot of the 'decision of a few representatives or officials' rather than a wise vigilance for collating informed public opinion (Little, 1996:347). Nevertheless, some scholars like Ebienfa (2009) and Olaiya (2010) while deposing to the same school of thought have argued that laws and policies that emanates from the State perpetuate the interest of the ruling class much more to the detriment of the ruled. They argued that constitutions and legislations in States promote the interest of the dominant class controlling the means and power. Yet, no one had argued to downplay the role of law in the formulation of viable public policy.

\section{Law and Public Policy}

Public policy discourse has undoubtedly transcended the period of time when analysts consider them and the successes they can facilitate in isolation of the political will and its general acceptability. In the justifiable opinion of Ebienfa (2009), notwithstanding numerous public policies that could serve to alleviate the burden of governance crisis in Nigeria, the unfortunate absence of political will stands in the way of the realisation of set policy objectives. As Adam and Balfour (1998:135) argued the whole essence of public policy as typified in the contemporary decision making situation is largely 'to identify, develop, and implement solutions to an array of discrete social problems'. According to them, the reflection that public policy is a problem solving mechanism is gaining the necessary momentum against the backdrop that governance situation now presents 'rather uncommon instances' that require that 'the technology for addressing the problem is known and a political consensus exists on the goals of the policy (Adam \& Balfour, 1998:134-36). It would therefore appear that the 
platform for ensuring public policy formulation must be concrete, available for easy interpretation, and largely predictable in its minimum sense by ordinary citizens.

There is no gainsaying, therefore, the fact that public policy should be embodied in constitutions, legislative acts, and judicial decisions in order to guarantee its stability and potency. In his Seminal essay entitled "The Study of Public Administration" published in the Political Science Quarterly in 1887, Woodrow Wilson, a scholar and $28^{\text {th }}$ American president, regarded as the founding father of the modern public administration defined public administration as "detailed and systematic execution of public law" (Wilson, 1887). Juxtaposing Woodrow Wilson's time-hallowed definition with the definition of public policy as a purposive and consistent application of law to a course of action produced in response to a social crisis of a constituency, formulated by a specific political process, and adopted, implemented, and enforced by a public agency, it ought to leave no room for misconception that public policy and law are inextricably interwoven (not interdependent). Like epiphyte and its host plant - the former grows non-parasitically and derives its moisture and nutrients quasi-independently from the latter and/or from accumulating values around it instead of the structure - so do public policy derives its expediency and value from law.

In yet another analogy, public policy is to law what the cantilevered beam is to base structure called fulcrum to a structural engineer. The extra square footage provided by cantilever allows for crucial extension beyond a fulcrum, when occasioned, covering more space and, yet, is supported by a balanced base or a downward force provided by the fulcrum. In social parlance, apart from law that will form the framework, the real feeders and shapers for emergence and sustenance of public policy are the ever-dynamic societal perceptions and expectations as well as the political will of the moment. The law, comprising constitutional provisions, legislations, case laws, and the native law and customs, however provides the structure on which public policy derive its support. Succor or support therefore, the position of law to public policy appears superior as the former constitutes the stability upon which the latter's social fabric is built. Yet, public policy, properly grounded, is much more assertive than law due to its fluidity and adaptation to societal changes. Public opinion, more often than not, shapes public policy. As the public becomes progressively opinionated about a social problem, the law responds characteristically through the dynamism of public policy.

Indeed, this line of thought could have come handy to allay the fear of the great German jurist, Friedrick Karl von Savigny, the influential head of the historical school of jurisprudence pioneered in the first half of the 19th century while studying the relations between the society and law. As Kutner (1972:287) argued, Savigny vehemently opposed the codification of law, i.e. reducing a people's whole stock of law to writing, because 'no amount of state authority could produce a real, suitable, or stable code' in any political system, least of all the ones in transition. The law, according to the historical school, is the constitutive will of the people. To think of law as self-exhaustive and amenable to be codified is to denounce the ever-changing consciousness of the people and make law a highland of its own because it will, so doing:

inevitably attract $[\mathrm{ALL}]$ attention to itself, away from the real source of the law, so that the latter, left in darkness and obscurity, would derive no assistance from the moral energies of the nation, by which alone it could attain a satisfactory state. (Stone, 1946:423)

However, the great influence of Savigny's historical school hardly exists in the contemporary world. Most States now possess a single, unified code of laws populated from various sources. In Nigeria, the sources of law, which are the Constitution, The Received English Law (comprising Common Law and Equity aand Statute of General Application (SOGA)), Acts of Parliament, case law, etc, are well coded (Asein, 2005). The only exception being the native law and customs has been codified in some sense by various provisions of constitutions, Acts, civil procedures, which have delimit its application or set rules as to how and which of the organic laws of the indigenous people will be applied in the Nigerian courts. By virtue of section 36(12) of the 1999 Constitution, "a person shall not be convicted of an offence unless that offence is defined and the penalty thereof is prescribed in a written law". Similarly, by the combined effect of provisions of section 14(3) of the Evidence Act, section 13 Cap 46 Law of Oyo State 1978, decided cases, and a host of state laws across the federation, among others, the validity for the observance of which customary law is set, albeit selectively. For a native law and custom to be applicable, it must not be

(a) repugnant to natural justice, equity and good conscience;

(b) incompatible with any written law, either expressly or impliedly; and

(c) contrary to public policy.

There is no doubt, therefore, that codification of law and the attendant fear of inflexibility in addressing the 
dynamic and unique spirit of the people can be allayed with the advent of active public policies, which constantly correlate the law with national consciousness. Nevertheless, the most important modern law that gives impetus to public policy is the constitution, which, as explicated in the next section, is the comprehensive law of the land from which other laws derive their validity.

\section{Primacy of the Constitution and Directives on Public Policy in Nigeria}

Ebienfa (2009) argued, paradoxically, that the crisis is not only failure of existing public policies in Nigeria but also that there is no policy of public policy. The author hinged his cogent submission on the fact that the Nigerian policies, most especially for social rights, exist in vacuum with the necessary appendages of constitutionalism. The primacy of constitutions of States derives from the assumptions that the constitution is the collective will of the people. The 'We the people' perambulations that usually precede provision letters of constitutions can be cited as the attestations that the constitutions indeed represent the consent of the people. In the United States, the preambles to the American Constitution of 1787 reads "We, the People of the United States, in order to form a more perfect union, provide for the common defence, promote the general welfare and secure the blessings of liberty to ourselves and our posterity, to ordain and establish this constitution for the United States of America." In Nigeria, the preambles to the 1999 Constitution reads "We the people of the Federal Republic of Nigeria; Having firmly and solemnly resolve, to live in unity and harmony as one indivisible and indissoluble sovereign nation ....and to provide for a Constitution for the purpose of promoting the good government and welfare of all persons in our country, on the principles of freedom, equality and justice, ... do hereby make, enact and give to ourselves the following Constitution.

Manifest in all of these preambles is the appearance of a commitment to protect the socio-economic and politico-cultural rights of the people. A voyage through the Constitution of the Federal Republic (1999) would reveal two fundamental mention of the word 'public policy'. The first can be mention of Section 29(3)(b) which states inter alia that:

29. (1) Any citizen of Nigeria of full age who wishes to renounce his Nigerian citizenship shall make a declaration in the prescribed manner for the renunciation. (2) The President shall cause the declaration made under subsection (1) of this section to be registered and upon such registration, the person who made the declaration shall cease to be a citizen of Nigeria. (3) The President may withhold the registration of any declaration made under subsection (1) of this section if- (a) the declaration is made during any war in which Nigeria is physically involved; or (b) in his opinion, it is otherwise contrary to public policy.

The intendment in this mention seems to refer to repugnancy clause which could render such renunciation void. Such repugnancy test is also addressed towards customary law that is considered barbaric in context.

The real address of public policy in the 1999 constitution seems to be captured in Chapter II of the 1999 Constitution. The chapter contains the non-justiceable fundamental objectives and directive principles of State policy. The provisions of this chapter are non-justiceable to the extent that no one can sue the government of the day for failing to comply with the provisions. Yet, the chapter forms the bedrock of public policy formulation in Nigeria. Yet, Section 13 of the Constitution made an omnibus provision that seemingly ascribes compulsion on the apparatuses of government of Nigeria, as a matter of 'duty and responsibility', to observe the provisions of the constitution to letters. Among others, the provisions of the Chapter stipulate that the duty and responsibility of the government shall be geared towards the security and welfare of the people, who are the ultimate custodian of the sovereignty of Nigeria that is then transferred to the government through the constitutional provisions. In some cases, the letters of the constitution are brightly configured as though the educational, infrastructural, health and safety need, and other social cultural needs are to be unequivocally guaranteed. In fact, Section 17(3) of the constitution states, inter alia, that it is incumbent on the State to institute her program for the assurance of adequate means and facilities of basic livelihood to all citizens without discrimination. This, as provided infra, should encompass satisfactory employment befitting of an able and willing persons of working age. A percipience discernible from all these flamboyant provisions is that the government is duty-bound to its fulfillment.

As Olaiya (2010:259-260) pointed out, the rather long and seemingly positive provisions of the Nigerian Constitution (1999) should form the bedrock for public policy formulation in Nigeria. From the excerpt, it is clear that the provisions offer the template for achieving the promotion of 'good' governance and 'welfare of all persons in our country, on the principles of freedom, equality and justice' as proclaimed in the preambles to the constitution. Put differently, the provisions of Chapter II arguably correspond to rights of citizens in the social context. Thus, all policies of government regarding social rights are expected to take impetus and guidance from 
chapters II of the constitutions so as to secure their potency and constitutionality. Most especially with the supremacy clause contained in section 1(1-3) that all institutions must conform to the letters of the constitution. According to Section 1(1-3) of the 1999 Constitution:

(1) This Constitution is supreme and its provisions shall have binding force on the authorities and persons throughout the Federal Republic of Nigeria. (2) The Federal Republic of Nigeria shall not be governed, nor shall any persons or group of persons take control of the Government of Nigeria or any part thereof, except in accordance with the provisions of this Constitution. (3) If any other law is inconsistent with the provisions of this Constitution, this Constitution shall prevail, and that other law shall, to the extent of the inconsistency, be void.

This scenario will hold except in times of military rule when the authority of the constitution is sidelined in favour of the abrogating decree. For instance, during the first coup led by Major-General J.T.Y. Aguiyi Ironsi, the key constitutional instrument, following the suspension of the Constitution of the Federation (1963), was the Constitution (Suspension and Modification) Decree No. 1 of 1966 issued by the Head of the Federal Military Government. From 1966, therefore, the 1963 Constitution itself took authority from Decree No. 11966. Accordingly to its amended wording the Constitution of the Federation as modified by the Decree prevails over and renders pro tanto void ante other law which is inconsistent with it except a Decree: no part of a Decree may be rendered void by the Constitution (See Section 1 of No 20 of 1963 as amended by Decree No. 1 1966). Barring military regimes therefore, the public policy domain should take complete cognizance and departure from Chapter II of the 1979, now 1999, Constitution.

\section{Constitutionalism and Entrenchment of Social-Economic Rights in the 1999 Constitution}

Constitutionalism is a concept that has attracted extravagance attention, perhaps only next to democracy or democratization. Yet, defining constitutionalism remains a challenge. Mangu (2004) asserted that defining the concept have raised more polemics and diverse understanding than a clear-cut definition. Despite, we attempt here a presentation of some of the attempts, or controversy, that could give a passing understanding of the concept. According to Rosenfeld (1994), constitutionalism is a concept that can be described from three dimensions, which are imposition of limits on governmental powers, strict observance of rule of law, and the protection of the social rights of the citizens. Mcllwain (1947) argued that Constitutionalism abhors arbitrary rule., despotism in governance, and advocates the government predicated on rule of law rather of whimsical disposition of rulers.

Constitutionalism has been defined by Chief Afe Babalola (2010:14) as 'the application of the constitution in governance or government according to the constitution'. He further argued that because the constitution is the umbrella law for all other laws, 'it means necessarily that constitutionalism in the rule of law or rule by law i.e. the observance of the express and implied contents of the constitution and its duly begotten laws in the actual conduct of governance' in 'contra-distinction with arbitrary or personal idiosyncratic rules' (Babalola, 2010:14). Möllers (2011) argued, like Babalola (2010) that constitutionalism is rather a concept still evolving. He described constitutionalism as an institutional phenomenon that links law and politics without completely accommodating the differences between both. According to him, a central element in constitutionalism is that political power is legalised, in such a way that politics and public administrations became subjected to the rules they had made, with the court plying the role of umpire. The whole essence here is to view constitutionalism as the process by which the collective wills of the people is transformed into and reflected in the public policies of the society. This process translates into the general law of the state that in turn ensures that the collegiate interest of the people are not only recognised but also enforced appropriately.

Walker (2009:15-16) described a 'holistic' concept of constitutionalism in which authorities and social components operating within a state depend on the 'integrity of the whole' constitution. He raised a dichotomy between constitutionalism studied in the abstract sense i.e. as a theoretical concept for appraising the social world, and constitutionalism understood in the tangible sense as practiced in the 'social world of the state'. Theoretical constitutionalism refers to the conduct of the affairs of the State according to the letters and spirit of the constitution. According to him, constitutionalism in the concrete sense refers to the concept of state constitutionalism viewed both diachronically and synchronically. Diachronically, he referred to the accumulation of modern constitutional practice like juridical, politico-institutional, popular and societal that have become registered due to their continued operations in the past.. Synchronically, he pointed to the formulation of these recognised practice and the interconnectedness among them.

Constitution itself refers to an all-encompassing legal document complete with rules of self-production, self-organisation, self-extension, self-interpretation, self-amendment and self-discipline, all of which combine to 
affirm the autonomous existence and comprehensive authority of the legal order against other internal and external forces. As Woodrow Wilson (1887) pointed out, the major concern of constitutions is those instrumentalities of government, which are to control general law. He literally described as anti-progressive a constitution observes that speaks only of that executive and legislative powers and how to share the legislative and policy-making functions of government and only of judicial jurisdiction and its functions as interpreters and guardian of the principles of the constitution, and nothing of provisions that will stamp the policies or, at least, give utterances to them. There is no doubt that Wilson's (1887) effusion epitomized the Nigerian case, if not worse. As argued earlier, Section 6(6)c of the 1999 Constitution, by making Chapter II non-justiciable, not only prevents the carriage of social justice it also stamps the miscarriage of justice to a free and just society.

Perhaps this ease of confusion may explain such utterances as that of Niebuhr's, quoted by Wilson (1887) that 'Liberty depends incomparably more upon administration than upon constitution." However, a cursory reflection on, as Wilson (1887) deduced, could signify that the exercise of liberty depend more upon administrative arrangements than upon constitutional guarantees. A deeper emendations, he argued, reveals that the constitution remains 'the principles that rule within the man' and 'the vital springs of liberty or servitude'. He affirmed that public policy on and administration of social equity and liberty alone, notwithstanding how perfect and liberal the principles upon which it is grounded 'can give men more than a poor counterfeit of liberty' as 'Liberty cannot live apart from constitutional principle'. Moreover, since a philosophical study of administration trenches on constitutional ground most especially as it concerns proper distribution of constitutional authority, the simplest arrangement to guarantee efficiency is to concentrate on constitutional responsibility as they are unmistakably fixed upon officials. By so doing, authority will be assigned 'without hampering it and responsibility without obscuring it'. Thus, the 'distribution of authority, when taken into the sphere of the higher, the originating functions of government, it is obviously a central constitutional question'.

However, there are grounds upon which an unqualified grant of opportunity to redress social rights can be justified. Wilson (1887) argued that 'all sovereigns are [usually] suspicious of their servants', and vice versa. The State, ab initio, being an instrument for struggle. Quoting Engels, Ebienfa (2009) had argued that the State, is an instrument for class rule, in which the mighty dominate and oppress the weak, whereby the 'State' acts as the legitimizing force(s) or "order" by 'moderating the conflict between the classes' with a view to perpetuating oppression. Thus, for reasons of strengthening the government against multiplicity of litigations from disgruntled citizens; and especially for the avoidance of the abuse of such wide privilege for political purposes, governments usually refrain from enshrining the rights into the constitutions. Without doubts, as obtainable in advanced democracies, such rights may form part of accepted norms for governance, only that they their existence is conscientious. Even, where the constitutions recognise the existence of such rights in written forms like the case of Nigeria, Ghana, India, etc, there are always necessary concomitant provision ensuring that such rights are not actionable in law courts. Yet, as Wilson (1887) pointed out, to ensure the potency of our public policy and insure them against possible failure 'we have only to filter [them] through our constitutions' and put them over a slow fire of misrepresentation that leads inevitable malfunctions so as to distil away their failures.

\section{The Scenario of Public Policy Failure in Nigeria}

Nigeria is not bereaved of public policies: the problem is most of them, as Omotosho (2013:126) pointed out 'ended in fiasco'. For instance, the Obasanjo administration had initiated so many laudable policies intended to salvage the ailing economy and governance in terms of growth and development. Some of these policies, he argued, are the Monetisation Policy; National Economic Empowerment Development Strategies (NEEDS); Economic and Financial Crimes Commission (EFCC); Independent Corrupt Practices and Other Related Offences Commission (ICPC); Banking Reforms; Revitalisation of the National Food and Drug Administration (NAFDAC); Constitutional Conference; Policy Towards Poverty Reduction/ Alleviation - SMEDAN, PAP, SMSE etc; Privatisation Policy; Emphasis on Infrastructural Development; to mention a few. As rightly averred, no sooner had the policies formulated than 'most of them ended in fiasco' and thus deepening the frustration and impoverishness of the citizens. Iluyomade and Eka (1992:3) wrote that in one single Gazette in 1976, a number of public policies were initiated leading to the establishment of 'no fewer than twenty-five public agencies'. These included at least 10 River Basin Development Authorities (RBDA), the Nigerian Security Organization (NSO), the News Agency of Nigeria (NAN), the Nigerian Export Promotion Council (NEPC), the Nigerian Airport Authority (NAA), the Nigerian Atomic Energy Commission (NAEC), the National Emergency Relief Agencies (NERA), etc. Similarly, the period also saw a geometric increase in the quantity and cost of governance without visible qualitative impact on the citizens.

There are plethora of studies explaining the failure of policy process in Nigeria, some of which include Omotosho (2013), Olaiya (2010a), Olaiya (2010b), Oyelaran-Oyeyinka (1997), Ekuehare (1996), Ikpeze et al (1991), Soleye 
(1987), Oyejide (1975), Egbon (1975), Adamolekun (1983), to mention a few. Ebienfa (2009) argued, paradoxically, that the crisis is not only failure of existing public policy in Nigeria but also that there is no policy of public policy. However, most of the works have been technocratic exposure of the country's public policy analysis and others from the perspectives political and sociological aspects of African policy process (Ikpeze et al, 2003). There are also studies which attempt to cage failure in public policies in Nigeria as a product of disjointed and fragmented nature of policy follow-up (Makinde, 2005). Specifically, Ademisokun-Turton (1992) admits that:

Nigeria's industrial policies, objectives and strategies are often subject to either modifications, or neglect or even total abandonment. In other words, industrial policies and practices are pursued on an ad-hoc basis and in a most uncoordinated manner. This major shortcoming partly explains the reason for the concentration of Nigeria's few industries in major cities like Lagos, Kano, Ibadan, and Port Harcourt, the centres of political power of the ruling elites. This partly explains why industrial location is not solely a function of reasoned entrepreneurial planning and decisions, since political considerations are often given undue weight.

Every finger seems pointing at poor implementation as though the policies in themselves, howsoever incongruent they are to the problem at hand, could have succeeded were they to be properly and strictly implemented. To drive home the implementation argument, Makinde (2005:64-66) quoted extensively from Honadle (1979) by drawing analogy of policy implementation problem with that of 'social carpenters and masons who fail to build to specifications and thus distort the beautiful blue print'. She quoted Honadle (1979) as follows:

Implementation is the nemesis of designers, it conjures up images of plans gone awry and of social carpenters and masons who fail to build to specifications and thereby distort the pattern handed to them. It provokes memories of "good" ideas that did not work and places the blame on the second (and second-class) member of the policy and administration team.

The above quotation and its cohort over-amplified the importance attached to policy implementation and those that are responsible for implementing these policies. It also shows that no matter how bad the blueprint of a programme is, an effective implementation of it will make sense of in whole shenanigans. An obvious neglect lies in considering the atmosphere in which policies are made. It is discernible that most often than not, most policies were construed from requisites of politics with the hard realities of the needs of the target people distantly relegated to the background.

The implementation argument also failed to consider the high-stake politics of eliticism and hegemony in Nigeria where the fight for booty or national cake is ferocious and often malicious. The debilitating effect of heated political phenomenon can hardly be curtailed by 'good' policy implementation. Garba (1995) came close when he observed that most of Nigerian policies are tended in chequered antecedents. According to him:

Who gains, who loses in these federal, state and local policy arenas is rarely an accident. More often than not, the distributional consequences of public policies are the intended result of the private interests which have been instrumental in their design, passage and implementation. For the entire country, the manipulation of public policy for private purposes comprises yet another disjunction in our fractured history. Not every public policy fails; and not every public programme or project is redundant. But when once in a while a policy succeeds, it is often not because of government per se, but in spite of it (Garba 1995: 237).

Ekwueme rebuts the implementation argument that the Nigeria's constitution is not all that defective but that its problem lies in the way it is operated. He argues that

It is often said in Nigeria that there is nothing wrong with our several constitutions but that what is all wrong is with the operators of the constitutions who distort and abuse their provisions and do not play by the rules of the game. I do not endorse this view, for if the country is not made up of angels who will operate the constitution but is made up, instead, of rogues and vagabonds, then it is only proper that the constitution in place should be tailored to suit rogues and vagabonds, and not angels, as its operators" (Ekweme, 2005: 2).

Considering the above, and going by the effusion of Lane (2000:33) that 'the fate of public policies depends on both how the policy [is] enacted [and] is implemented and the nature of the organizations which are the target for policy implementation', it goes without saying that the hollow base from which Nigerian public policy, most especially as it affects social rights of citizens are a significant source in the policy failure discourse waiting to be explored. 


\section{Non-Justiciability of Social Rights in Nigeria: Arguments for and Against}

The most favored arguments advanced by proponents of non justiciability of social rights is often cited from the text of Article 2 of the International Covenant on Economic Social and Cultural Rights (ICESCR), which Nigeria ratified and adopted on $29^{\text {th }}$ July, 1993, where it has been argued that social rights are conditional ends that cannot be enforced against the State. The International Council on Human Rights Policy (ICHRP) argued in 2005 that this largely resulted in the provisions being expressed in State constitutions as 'obligations and not individual rights' (ICHRP, 2005:9). According to Article 2 of the ICESCR,

[e]ach State Party to the present Covenant undertakes to take steps... to the maximum of its available resources....to achieve progressively the full realization of the rights recognized in the present Covenant by all appropriate means, including particularly the adoption of legislative measures.

In this light, Ebobrah (2007:116-17) contended that 'socio-economic rights are at best programmatic provisions and confers no immediate and enforceable right on individuals'.

The second most advanced argument is discernible in the legal implication of section 6(6)(c) of the 1999 Constitution and its consequence for justiciability of socio-economic rights in Nigeria. While vesting the judicial powers of the federation in the courts, section 6(6)(c) of the 1999 Constitution states that the judicial powers vested accordingly

Shall not, except as otherwise provided by this Constitution, extend to any issue or question as to whether any act or omission by any authority or person or as to whether any law or any judicial decision is in conformity with the Fundamental Objectives and Directive Principles of State Policy set out in Chapter II of this Constitution.

In addition, apart from the courts lacking capacity to make articulated decisions about implementation and enforcement strategies, it is also argued that making socio-economic rights enforceable vitiates the principle of separation of powers in that it allows 'unelected' judicial officers to tinker with the role of legislature to make law and that of executive to execute the law (Ebobrah, 2007). Moreover, because social rights 'are usually formulated in vague and indeterminate language' it presents a complexity for judicial implementation in serious wrongs that can be remedied. For instance, the provisions in chapter II of the Constitution is cast in subordinated language in the like of 'Government shall direct its policy towards ensuring...', compared to the language in chapter IV of the same constitution that assertively provided that 'Every person has a right to...' or that 'Every person is entitled to...'. As Ebobrah (2007:117) rightly pointed out, 'whereas the former provisions may impose a duty on government, they do not confer individual rights that can be invoked in court'.

Yet, there are reasons to justify the invocations of these same social rights in law courts. Foremost in this regards is the contention that chapter II of the 1999 Constitution, even though decidedly made non-justiciable, is not cast to the exclusion of what is known as socio-economic rights. Ebobrah (2007) argued that social rights are 'conglomerate of several rights, ideals and programmes' not exclusively captured in the text of Chapter II. Ipso facto, Section 6(6)c clause making chapter II non-justiciable is not holistically directed at all conceivable and emerging socio-economic rights but at the contents contained in the text of chapter II of the constitution. In $A G$ Ondo v. AG Federation, (2002) 9 NWLR (Pt 772) 418, the Supreme Court emphasized, the provisions of a statute (including the Constitution) must be read in their plain and ordinary meaning which best give their meaning where they are clear and unambiguous.

Proponents of this school of thought also averred that even though section 6(6)(c) clearly declares that chapter II is not justiciable, it does not appear to tamper with the parliamentary power to make laws that can confer actionable rights on the contents of chapter II (Ebobrah, 2007). It then comes to fore, the provisions in Item 60(a) of the Exclusive Legislative list (Part I Second schedule) of the 1999 Constitution, which empowers the National Assembly to enact laws for the 'establishment and regulation of authorities...to promote and enforce the observance' of chapter II of the Constitution. In a situation where the legislature takes positive steps in this direction, the contentious provisions in Section 6(6)c would have been rendered impotent and right of access to a court for the enforcement of such a right by an aggrieved citizens will receive the much-needed boost, 'just as nothing removes the competence of a court from entertaining such a case'.

Another strong point against non-justiciability of Chapter II is the provisions of African Charter containing several articles that confer socio-economic and cultural benefits on citizens and its important domestication in Nigeria via [t]he African Charter on Human and Peoples' Rights (Ratification and Enforcement) Act Cap 10, Laws of the Federation of Nigeria (LFN). With this, it can be validly argued that by logical implications, 
socio-economic rights are actionable in the Nigerian courts notwithstanding the provisions of section $6(6)(\mathrm{c})$ of the Constitution to the contrary. Reinforcing this submission is the non-recognition of "traditional" or "generational" approach to socio rights protection, which renders a dichotomy between civil and political rights (CPRs) and economic and social cultural rights where the former are justiciable and the latter are not.

Beyond the level of mere speculative and theoretical exposition, the Nigerian courts have also invoked the justiciability of social rights in various judicial pronouncements notwithstanding the provisions of section 6(6)(c) of the Constitution. Even though the Supreme Court is yet to pronounce on the issue, there are plethoras of cases from the lower superior courts that have give strength to the circumstances. In a Court of Appeal case, Oronto Douglas v Shell Petroleum Development Company Limited, (1999) 2 NWLR (Pt 591) 466, the Court endorsed the justiciability of an action brought pursuant to article 24 of the African Charter (Ratification and Enforcement) Act. Ebobrah (2007) opined that these judicial pronouncements tend to purport that the provisions of article 24 of the African Charter are similar in manifestations to the provisions of Chapter IV on the actionable civil rights of the 1999 Nigerian Constitution. Similarly, in an unreported Suit no. FHC/B/CS/53/05, Gbemre v Shell Petroleum Development Company Nigeria Limited and 2 ors, the Federal High Court in Benin City also upheld an action based on article 24 of the African Charter (Ratification and Enforcement) Act.

Nevertheless, uncertainty still beclouds the fate of public policy cast in respect of social rights in Nigeria. The prevailing situation is that the constitutional provisions contained in Section 6(6)c are still being invoked to a large extent still make the terrain of public policy of social rights murky waters. The general trends tend to be that that despite these pockets of legislative, supra-national conventions and judicial authorities in favour of the justiciability of social rights, the supremacy of the constitution still understandably holds sway. This indeed is a pointer to the fact that nothing short of a holistic approach, like an amendment to the letter and spirit of the seemingly inviolable clauses in Section 6(6)c of the 199 constitution, social rights and public policies fashioned to cater for the welfare of the citizens will remain at large.

\section{Socio-Economic Rights and Failure of Nigeria's Public Policy}

The letters of Chapters II of the 1999 constitution are quite comprehensive to the extent that public policy in Nigeria should be robust if crafted around it. For instance, major public policies like the education, health, etc are well-grounded in the Chapter. The problem is the counter-provisions of Section 6(6) of the same constitution that foreclosed the justiciability of these provisions by the citizens. The argument here is that these helter-skelter status of the constitutional provisions on major aspect of public policy did result in lack of commitment on the part of government to these welfarist issues. If anything, the policies that bordered on socio-economic and cultural needs of the citizens are merely promulgated without intention to be bound by them.

The 1999 constitution ably provides that government shall ensure 'free, compulsory and universal primary education' in addition to this is that secondary and university education should be free. Concerning primary education, a discerning mind could be tempted to assume that the word 'compulsory' impugn that all children of primary school age are automatic responsibility of the government. The same could be discerned towards secondary and university education, which supposed 'free' as the constitution stipulates. In fulfilling these, it would be expected that public policy on education would be direct and pungent in addressing the 'compulsory' and 'free' education provisions. This, obviously, is not the case. For instance, the lack of focus reflected in the uncoordinated education programme of the country with high infiltration from the private sector. This lack of coordination has resulted in multiplicity of curricular activities being perpetuated in the schools; especially as it concerns the primary and post-primary institutions. The private schools are indeed free to determine all the administrative and legal and curricular programmes in their respective schools, including the exorbitant fees and textual provisions. The resultant effect of this is that, even though a greater deal of money are being expended on wards in the recent time, in comparison to the past, the standard of education in Nigeria is apparently falling. The same can be said of the haphazard public policy on health and public safety, where the citizen are left largely unprotected presumably because the government cannot be held accountable for any neglect that leads to insecurity of health and lives and property of the people.

\section{Conclusion}

There can be no doubt that policy failure is part of the 'devil' inhibiting the achievement of policy objective in Nigeria. The situation becomes more forlorn in the aspect of socio-economic and politico-cultural rights of citizens embodied in Chapter II of 1999 Constitution of the Federal Republic of Nigeria, on the one hand, and made unreachable mutatis mutandis by Section 6(c) of the same constitution. This study explored the seeming contradictions within such provisions and counter-provision on an aspect of governance considered by scholars as very pivotal to democratic governance. The study analysed the essential roles of law and constitution in public 
policy frameworks against the backdrop of the situation in Nigeria where most of the policies, especially those pertaining to welfare and social rights of the citizens, lack the necessary constitutional vertebrae. The constitutive effect of these, as explicated in the paper, is that the Nigerian social policies are formulated extempore making the entire policy evaluation difficult, if not forlorn. While analysing the nitty gritty of the issues in question, evidences bordering on legislative, international treaties and conventions as well as judicial authorities on the justiciability of social rights were discovered. These, if properly followed, could have mended the hollow framework in which the Nigerian social right policies operate.

The study also found evidences of hasty condemnations of formulated policies on socio-economic rights without an in-depth analysis of the queer and flawed process of policy formulation in itself. There are evidences from scholarship to establish the importance of formulation antecedents and process as critical to policy successes in Nigeria (Olaiya, 2010a; Olaiya, 2010b; Ebienfa, 2009; Koehn, 1983; Aminu, Tella \& Mbaya, 2012; Paki \& Ebienfa; and Ugwuanyi \& Chukwuemeka, 2013)

To this end, and bearing in mind the need to formulate enduring public policies in the area of economic and socio-cultural rights, the study concluded on the following critical stance: (a) There is urgent need to promulgate laws that will serve as the backbones of policies on economic and social rights not only to ensure consistency but also to foster continuity; (b) there is also the need to be more constitutional in all aspects of the formulation of social right policies to prevent abuse in the highest possible regards and, most importantly, to ensure popularity of the policies as the constitution is the mother law that a good number of members of the society are familiar with; and the prevailing situation of lack of assertive position by the courts between the provisions of Section 6(6)c of the 1999 Constitution and Article 24 of the International Covenant on Economic and Social Rights (ICESCRs) should be resolved, either by outright amendment to the relevant part of the 1999 constitution or by the legislature exercising its power in Item 60(a) of the Exclusive Legislative List.

\section{References}

Adamolekun, L. (1983). Public Administration: ANigerian and Comparative Perspective. New York: Longman Inc.

Adams, G. B., \& Balfour, D. L. (1998). Unmasking Administrative Evil. Thousand Oaks: SAGE Publications, Inc. http://dx.doi.org/10.4135/9781452231525.n6

Aminu, A. A., Tella, C. M., \& Mbaya, P. Y. (2012). Public Policy Formulation and Implementation in Nigeria. Public Policy and Administration Research, 2(5), 57-62. Retrieved from http://www.iiste.org

Babalola, A. (2010). Constitution and Constitutionalism. Retrieved from http://www.afebabalola.com/downloads/Constitution_and_con.pdf 30/3/14

Duru, O. W. C. (2013). The Justiciability of the Fundamental Objectives and Directive Principles of State Policy under Nigerian Law. Retrieved from http://papers.ssrn.com/sol3/papers.cfm?abstract_id=2140361 on $31 / 01 / 2014$

Ebienfa, K. I. (2009). The Nigerian State and the Politics of Public Policy Implementation. A Publication of Centre for the Advancement of Socio-Political and Environmental Justice. Retrieved April 25, 2014, from http://kimiebi.blogspot.com/2009/12/nigerian-state-and-politics-of-public.html

Ebobrah, S. T. (2007). The Future of Economic, Social and Cultural Rights Litigation in Nigeria. Review of Nigerian Law and Practice, 1(2), 108-124.

Egbon, P. C. (1995). Industrial Policy and Manufacturing Performance in Nigeria, Ibadan: National Centre for Economic Management and Administration (NCEMA).

Ekuerhare, B. U. (1996). Design and Management of Sectoral Policies in Nigeria: Industrial Policy under SAP. In M. I. Obadan, \& M. A. Iyoha (Eds.), Macroeconomic Policy Analysis, Tools, Techniques and Applications to Nigeria. Ibadan: NCEMA.

Garba. (1995). The Impact of Oil on Nigeria's Economic Policy Formulation. Text of a paper presented at the conference on Nigeria: Maximizing Pro-poor Growth: Regenerating the Socio-economic Database, organized by Overseas Development Institute in collaboration with the Nigerian Economic Summit Group, 16th / 17th June 2004

Ikpeze, N. I., Soludo, C. C., \& Elekwa, N. N. (2003). Nigeria: The Political Economy of the Policy Process, Policy Choice and Implementation. Retrieved from http://www.idrc.ca/en/ev-71263-201-1-DO_TOPIC.html

Iluyomade, B. O., \& Eka, B. U. (1992). Cases and Materials on Administrative Law in Nigeria. Ile-Ife, Nigeria: 
Obafemi Awolowo University Press Ltd

Koehn, P. (1983). The role of public administrators in public policy making: Practice and prospects in Nigeria. Public Administration and Development, 3(1), 1-26. Retrieved from http://onlinelibrary.wiley.com/doi/10.1002/pad.4230030102/abstract 25/04/14

Kutner, L. (1972). Legal Philosophers: Savigny: German Lawgiver. Marquette Law Review, 55(2).

Lane. J. (2000). The Public Sector: Concepts, Models and Approaches. London: Sage Publication Ltd. http://dx.doi.org/10.4135/9781446220085.n4

Little, J. H. (1996). Thinking Government: Bringing Democratic Awareness to Public Administration. In G. L. Wamsley, \& J. F. Wolf (Eds.), Refounding Democratic Public Administration: Modern Paradoxes, Postmodern Challenges (pp. 327-351). Thousand Oaks: SAGE Publications, Inc. http://dx.doi.org/10.4135/9781452233505.n13

Makinde, T. (2005). Problems of Policy Implementation in Developing Nations: The Nigerian Experience. Journal of Social Sciences, 11(1), 63-69.

Mangu, A. M. (2004). Constitutional Democracy and Constitutionalism in Africa. Retrieved March 30, 2014, from kms1.isn.ethz.ch/serviceengine/Files/ISN/104121/.../Chapter1. pdf

McIlwain, C.H. (1947). Constitutionalism: Ancient and Modern. Ithaca, New York: Cornell University Press (revised edition).

McSwite, O. C. (1996). Postmodernism, Public Administration, and the Public Interest. In G. L. Wamsley, \& J. F. Wolf (Eds.), Refounding Democratic Public Administration: Modern Paradoxes, Postmodern Challenges (pp. 198-225). Thousand Oaks: SAGE Publications, Inc. http://dx.doi.org/10.4135/9781452233505.n8

Möllers, C. (2011). The Guardian of the Distinction: constitutions as an instrument to protect the differences between law and politics. A preliminary draft paper. Retrieved March 30, 2014, from cosmopolis.wzb.eu/.../conkey_Moellers_Constitution-and-Constitutionalism

Newman, J. (2001). Modernising Governance: New Labour, Policy and Society. London: SAGE Publications Ltd. http://dx.doi.org/10.4135/9781446220511.n2

Okeke, G. N. (2011). Fundamental Objectives and Directives Principles of State Policy: A Viable Anti-Corruption Tool in Nigeria. Nnamdi Azikiwe University Journal of International Law and Jurisprudence, 2, 175-184.

Olaiya, T. A. (2010a). The Roles and Responsibility of Public Officials in Public Policy Formulation and Implementation. International Journal of Studies in Humanities (IJOSH), 7(8), 37-46. Int'l Association of Studies in the Humanities, University of Nigeria

Olaiya, T. A. (2010b). Examining the Legal Context of Public Policy Formulation in Nigeria. African Journal of Institutions and Development (AJID), V(7/8). Obafemi Awolowo University

Olaiya, T. A. (2012). Challenges of Public Policy and Good Governance in Nigeria. In I. O. Aransi (Ed.), Local Governments in Nigeria: Essays for Professor Oladimeji Aborisade (pp. 152-166). USA: Warren Publishing inc.

Omotosho, F. (2013). Governance Crisis and Democracy in Nigeria, 1999 - 2012. Mediterranean Journal of Social Sciences, 4(14). Retrieved from http://www.mcser.org/journal/index.php/mjss/article/view/1585/1594

Orewa, G. (1997). We Are All Guilty: The Nigerian Crisis. Ibadan: Spectrum Books Limited.

Oyejide, T. A. (1975). Tariff Policy and Industrialisation in Nigeria. Ibadan: Ibadan University Press.

Oyelaran-Oyeyinka, B. (1997). NNEWI: An Emergent Industrial Cluster in Nigeria. Ibadan: Technopol Publishers.

Paki, F. A. E., \& Ebienfa, K. I. (2011). Public Policy in Nigeria: An Implementation Paradox. Journal of Social Science and Public Policy, 3, 1-15. Retrieved from http://www.cenresinpub.org

Rosenfeld, M. (1994). Modern Constitutionalism as Interplay between Idenity and Diversity. In M. Rosenfeld (Ed.), Constitutionalism, Identity, Difference, and Legitimacy: Theoretical Perspectives (pp. 27-28). Durham \& London: Duke University Press.

Shivani, V. (2005). Justiciability of Economic Social and Cultural Rights Relevant Case Law, International Council on Human Rights Policy, 82 pages. Retrieved December 12, 2013, from 
http://www.ichrp.org/files/papers/96/108_Justiciability_of_Economic Social_and_Cultural_Rights_-_Relevant_Case_Law_Verma_Shivani_2005_background.pdf

Soleye, O. O. (1987). Nigeria's Industrial Policy: Retrospects and Prospects. In O. Iyanda (Ed.), The Nigerian Economy Issues and Problems of Management (pp. 3-10). Lagos: Malthouse.

Stone, J. (1946). The Province and Function of Law: Law as Logic Justice and Social Control: A Study in Jurisprudence. Oxford: Associated General Publications Pty Limited.

Ugwuanyi, B. I., \& Chukwuemeka, E. E. O. (2013). The Obstacles to Effective Policy Implementation by the Public Bureaucracy in Developing Nations: The Case of Nigeria. Singaporean Journal of Business Economics, and Management Studies, 1(8), 34-43. Retrieved April 23, 2014, from http://www.singaporeanjbem.com/pdfs/SG_VOL_1_\%288\%29/5

Walker, N. (2009). Multilevel Constitutionalism: Looking Beyond the German Debate. London School of Economics 'Europe in Question' Discussion Paper Series, Paper No. 08/2009. http://dx.doi.org/10.2139/ssrn.1550912

Wilson, W. (1887). The Study of Administration, Political Science Quarterly, 2, 197-222. http://dx.doi.org/10.2307/2139277

\section{Note}

Note 1. (1980) AIR SC, 1789.

\section{Copyrights}

Copyright for this article is retained by the author(s), with first publication rights granted to the journal.

This is an open-access article distributed under the terms and conditions of the Creative Commons Attribution license (http://creativecommons.org/licenses/by/3.0/). 